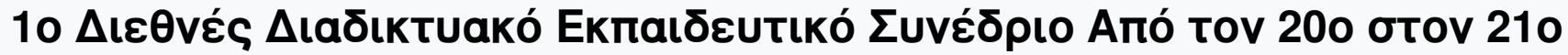

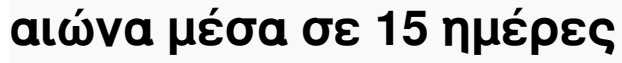

Ap. $1(2021)$

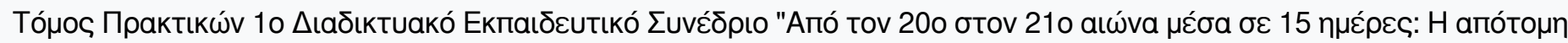

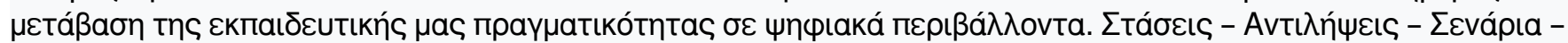

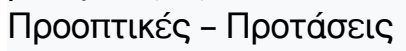

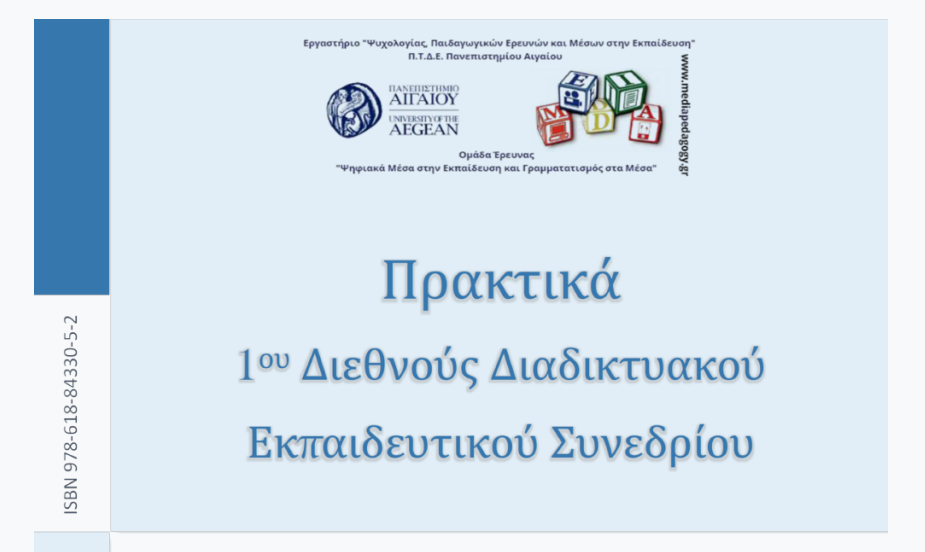

How do German schools cope with the Covid-19 pandemic? School during the corona pandemic in Germany

Petra Bauer, Christine Isabella Kolb, Alexandra Wiedemann

doi: $10.12681 /$ online-edu.3217

H $\alpha \pi$ tó

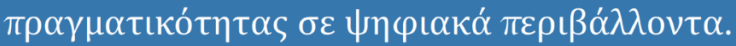

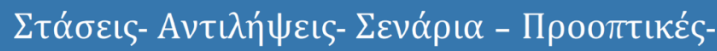

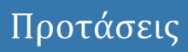

3, $4 \& 5$ Iovגíou 2020

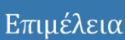

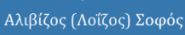

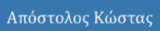

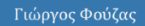

Baoìnıs Парй́oxou 


\title{
How do German schools cope with the Covid-19 pandemic? School during the corona pandemic in Germany
}

\author{
Petra Bauer ${ }^{1}$, Christine Isabella Kolb ${ }^{2}$, Alexandra Wiedemann ${ }^{3}$ \\ bauerp@uni-mainz.de, chkolb@uni-mainz.de, awiedemann@uni-mainz.de \\ ${ }^{1}$ Research Associates of Media Education, \\ ${ }^{2}$ Institute of Educational Science, \\ 3Johannes Gutenberg-University Mainz, Germany
}

\begin{abstract}
This article points out how German schools deal with the Covid-19 pandemic during and after the first national wide lockdown in spring 2020. The article describes the steps taken by the German Government concerning measures to combat the corona pandemic and the associated development of the framework conditions for schools. The different perspectives of teachers, students and parents during this time are reviewed based on the following studies KiCo and $\mathrm{JuCo}$, a nationwide online survey about experiences and perspectives of young people during the corona measures by the research association "Kindheit - Jugend - Familie in der CoronaZeit" and JIMplus 2020, an additional corona survey on media handling during school closure by Medienpädagogischer Forschungsverbund Südwest (mpfs). Finally, there will be a discussion based on the representative study "Deutsches Schulbarometer Spezial" about how teachers cope with the new tasks related to the corona crisis.
\end{abstract}

Keywords: school closure, home schooling, corona measures, digital support

\section{Corona pandemic in Germany}

This paper focuses on how German schools cope with the Covid-19 pandemic and provides an overview of the situation in Germany from a media pedagogic perspective. Due to the closures of schools and the gradual reopening of schools, the school leaders, teachers, but also parents and pupils, are in front of huge challenges and new, unknown situations that have hardly experience to overcome. Many schools have already taken the initiative and have found suitable solutions for them at an impressive rate.

The Covid-19 pandemic has been spreading from China since December 2019. The first case of infection in Germany was reported on January 27, 2020. On March 25, 2020, the German Bundestag determined an "epidemic situation of national scope" (Bundesgesetzblatt, 2020). The basis of the political measures to combat the pandemic is the National Pandemic Plan for Germany of March 2017 with its supplement to combat the Covid-19 pandemic of March 2020. It is a collection of instructions for action in the case of a pandemic in Germany (RKI, 2017).

The Covid-19 dashboard of the Robert-Koch-Institute provides a detailed description of the transmitted Covid-19 cases in Germany by state (Fig. 1). And in dealing with corona measures, this is the interesting part of it. According to the federal constitutional order of the Federal Republic of Germany, it is a country consisting of its partially sovereign states. Since 1990, the Federal Republic of Germany has consisted of 16 federal states and these states deal differently with the measures of the corona virus. According to the Federal Statistical Office, including vocational schools - there are around 43,000 schools in Germany with around 11

Aпó tov $20^{\circ}$ бTov $21^{\circ}$ aı

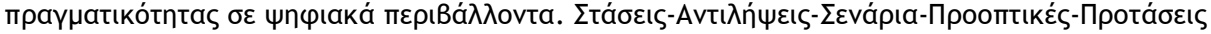


million pupils and 820,000 teachers. Many federal states are going their own way with regard to corona easing.

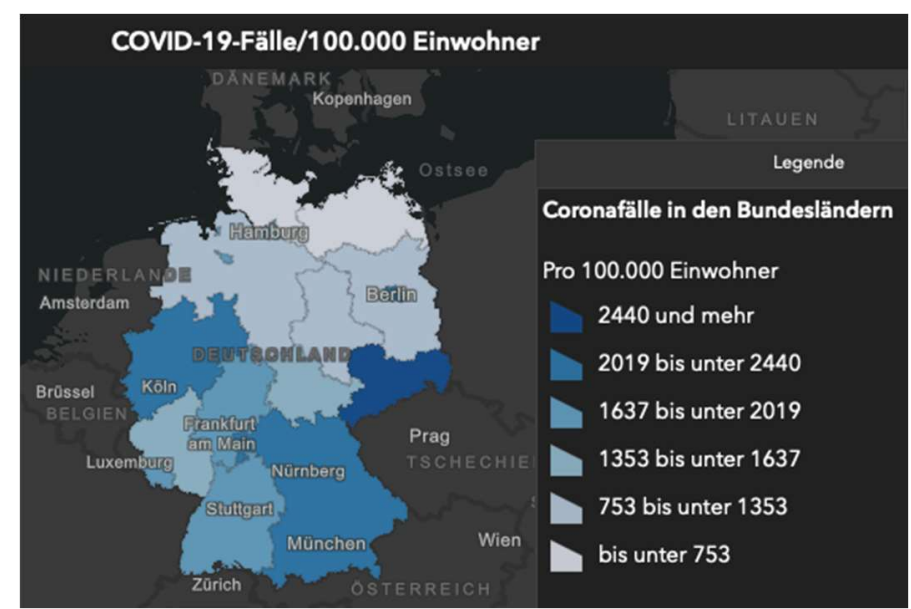

Figure 1. Robert Koch-Institute: COVID-19-Dashboard (23.12.2020).

In March, recommendations about cancellation of events with more than 1000 participants were published, along with a worldwide travel warning, and numerous shops were closed as well as contact restrictions and schools' closures. In April, there was a domestic quarantine obligation for returnees from abroad. Schools will gradually open from the 4th of May, shops under 800 square meters will open, no major events until the end of August, recommend everyday masks. Outdoor and recreational sports are permitted under hygiene and disinfection measures and the minimum distance is maintained. Visiting restrictions on clinics, nursing homes and facilities for the disabled will be relaxed. In schools and day-care centres, emergency care is being expanded. These measures are not all, but they all have the common aim to get more time. These measures of the Federal Government of Germany can be summarized with the \#flattenthecurve, in order not to overburden our health system (Fig. 2).

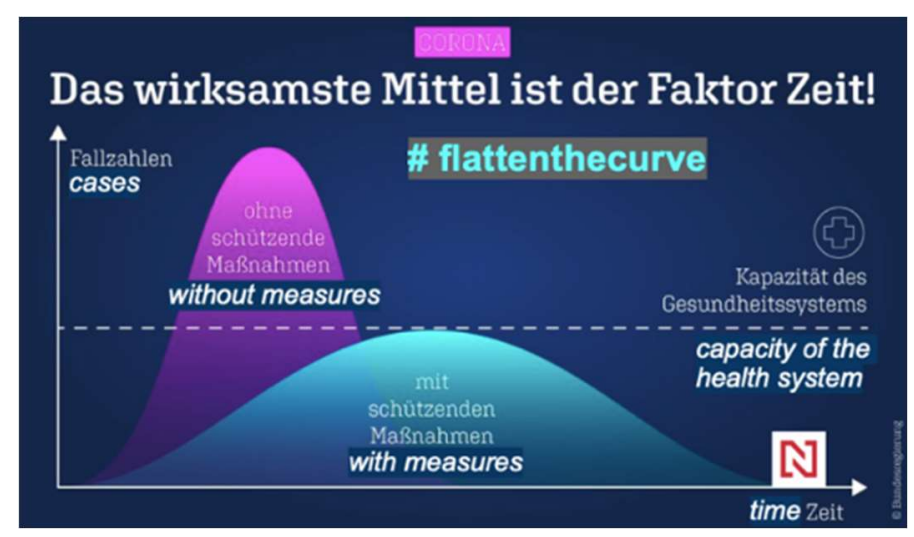

Figure 2. The most effective means is the factor of time.

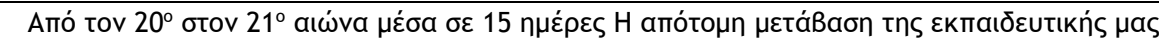

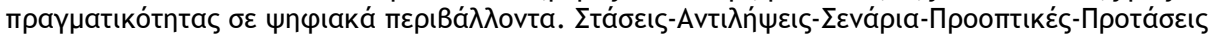


On the 13th of March and the following days, all federal states closed all schools nationwide. All countries established emergency care for children whose parents work in systemically important occupations. For all other children, teaching had to be largely done as distance learning at home. There have been many concerns that schools in Germany are not sufficiently prepared for digital education. Following a decision of the Conference of Ministers of Culture on the 16th of April, schools have gradually resumed classroom teaching since the end of April or the beginning of May. Initially, the graduating students returned to school. Classroom teaching and learning at home should alternate so that the learning groups are smaller and not all pupils are in schools at once. Day care facilities were only gradually reopened later and remained largely closed until June. The individual federal states decided in detail different opening dates and regulations. Universities and colleges of applied sciences stopped teaching in March and April until further notice. Based on the decisions of the federal and state governments, the summer and winter semester 2020/21 will largely take place as an online semester. In July 2020, the Federal Ministry of Health is putting a new corona test regulation into effect. In the future, people can also be tested for the coronavirus if they have no symptoms. The tests are paid for by the statutory health insurance companies. Comprehensive tests in nursing homes, schools or day-care centres will also be possible in the future. The corona warning app is available for download. The app helps determine whether a person has come into contact with an infected person and whether this could result in a risk of infection (VDAB, 2020).

Relating to the question how German schools cope with the Covid-19 pandemic, the answer is so far, there is no uniform regulation. Many schools have already taken the initiative and have found suitable solutions for them at an impressive rate. Federal and state governments provided 500 million euros for laptops and computers for disadvantaged students, among other things (Habermalz, 2020). Nationwide, distance and hygiene rules remain in place, social distancing, major events are prohibited.

\section{The corona situation from the perspective of students and parents}

The following part is about the experiences of students and parents at school during Covid19 pandemic. The research association Kindheit - Jugend - Familie in Corona-Zeit, which consists of the Institute for Social Pedagogy and Adult Education at the Goethe University Frankfurt in cooperation with the University of Bielefeld and the Institute for Social and Organizational Pedagogy at the Foundation University Hildesheim, conducted a nationwide online survey $\mathrm{KiCo}$ and $\mathrm{JuCo}$ for this purpose. The latter addresses the experiences and perspectives of young people during corona measures (Andresen, Lips, Möller, Rusack, Schröer, Thomas, Wilmes, 2020a). The KiCo survey addresses the experiences and perspectives of parents and their children during the corona pandemic (Andresen, Lips, Möller, Rusack, Schröer, Thomas, Wilmes, 2020b).

The target population for the JuCo study were adolescents between fifteen and eighteen years. In total, a data set of 5,128 evaluations was used. Of interest in this study was, for example, how young people dealt with contact restrictions, how satisfied they were with the situation in Covid-19, questions about their digital devices, their perception of the time before and during the pandemic and what new challenges young people experienced through Covid-19 (Andresen et. al., 2020a).

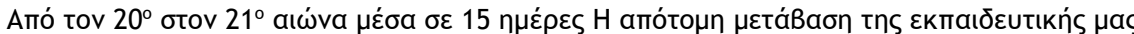

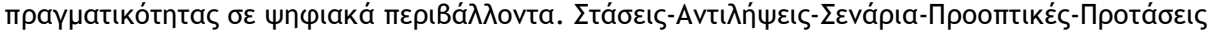




\section{About the findings}

The analyses of the individual statements shows the following: 3,653 students agree that there is always someone at home to take care of them. 650 students do not agree with this statement. When asked if there is always someone at home who can be contacted when problems arise, 3,691 voted YES and 640 voted NO. On a scale of 1-10 how satisfied the students are with the situation, an average value of 6.61 satisfaction could be evaluated (ibid.).

Furthermore, the study provided statements to the questions about contacts with other classmates (cf. ibid. p. 10f.). An average value of 4.95 was evaluated on a scale from 1-10. Additionally, almost all young people (99.2 percent) stated that they have their own digital device (i.e., computer, mobile phone/smartphone, laptop, or tablet) (ibid.).

Following the previous study, the online survey KiCo was conducted about the experiences from a parents' view on the situation with Covid-19. It took place during the period April to May 2020 and had about 25,000 participants (Andresen et. al., 2020b) and it is focused on questions about the everyday family life in times of the Covid-19 pandemic. Core questions were how parents and their children were doing, what their current well-being was, what characterized their daily life, how happy they were with the regulations on daycare, school opening and the general situation of workers.

The following data were evaluated in general on individual work patterns since the corona pandemic. " 47.4 percent of respondents with children under 15 years work from home. About a quarter (25.5 percent) occasionally goes to their working place because they can't do everything from home. 21.6 percent stated that there was no change to their regular situation at work. One in five is currently on leave, either through their employer, special leave, or parental leave. 11.2 percent are on short-time work and 1 percent receive corona support benefits" (ibid., p. 8). On the one hand, there was positive feedback such as "The stress about going to work, picking up children from school or from grandparents, taking them to hobbies, to friends, to other events is gone. I enjoy this time gained" (ibid., p. 12). Additionally, parents are in favour of their new "sparetime" and made statements like "I am very happy to see how much my children enjoy learning at home and what progress they make in a very short time. Their learning seems to be very effectively and with more enthusiasm than at school. I wonder if home schooling should become a legal option for families in Germany on a permanent basis" (ibid., p. 11). "There is more room for decision-making within the family".

On the other hand, parents suffer a lot from the Covid-19 situation, as the following comments shows: "I am happy to be able to use home office, but this makes me feel bad as a lot of work is left undone. This leads to an overload situation and there is not enough time to recover." (ibid., p. 13). The following comment illustrates that interviewees suffer a lot from the uncertainty based on the Covid-19 pandemic: "Grandparents are very sad and depressed, because of less contact with the family. My husband has less social contacts more and more now as well. This leads him towards dissatisfaction and bad mood. The uncertainty of when and how things will continue is a problem as well." (ibid., p. 14). Below are some tables that can be found in the survey:

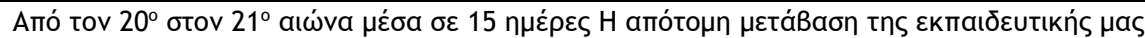

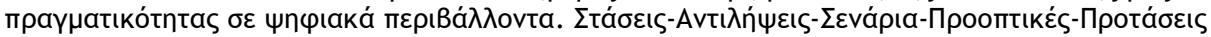




\section{Homeschooling: The families' perspective}

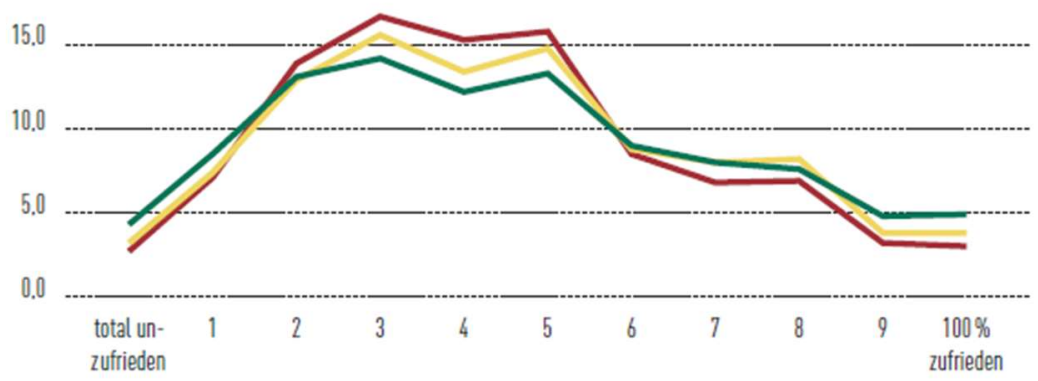

Figure 3. Satisfaction with home schooling (from dissatisfied $0 \%$ to satisfied 100\%)

When it comes to satisfaction about what their children have learned during home schooling, the parents tend to be neutral (Fig. 4), neither particularly dissatisfied nor particularly satisfied (ibid.).

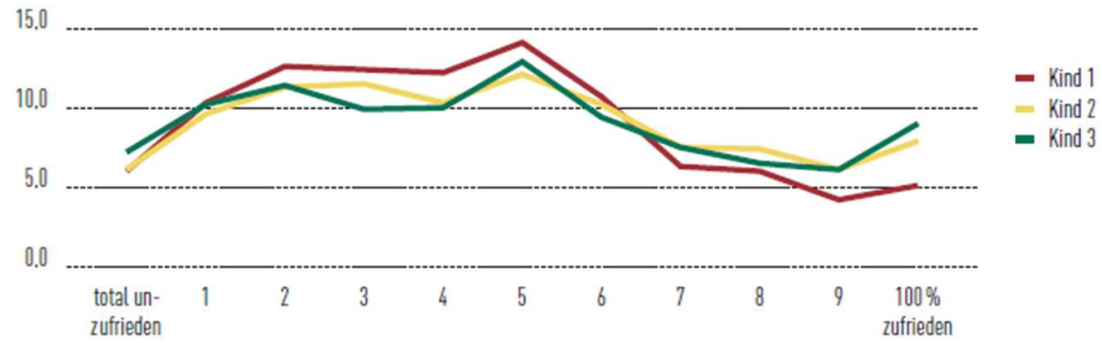

Figure 4. Satisfaction with support through teachers (from dissatisfied $0 \%$ to satisfied $100 \%$ )

When it comes to satisfaction about the support provided by teachers, the tendency goes toward dissatisfaction. Summarizing both results, it can be concluded that parents attribute learning success of their children primarily to themselves and less to the teachers. (ibid.)

\section{Mood at home}

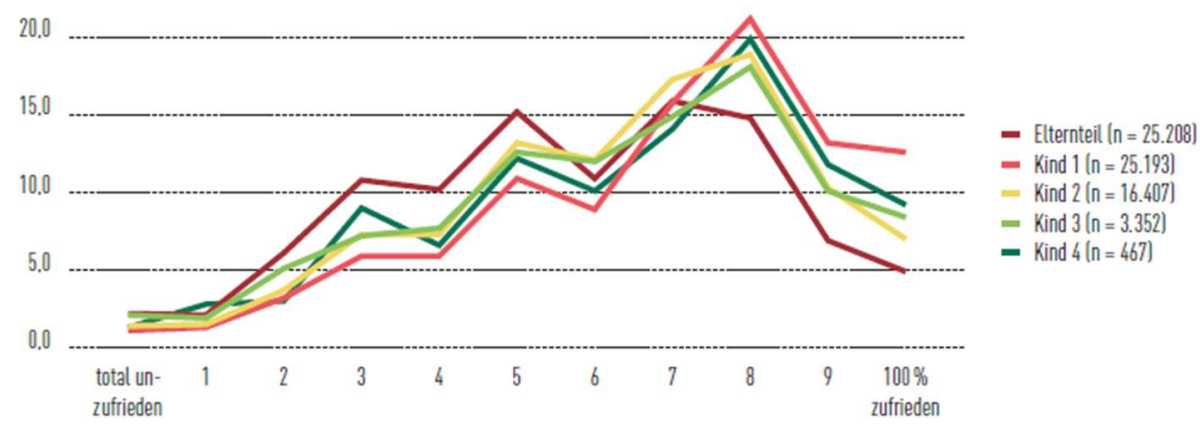

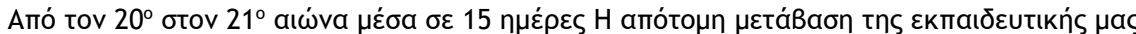

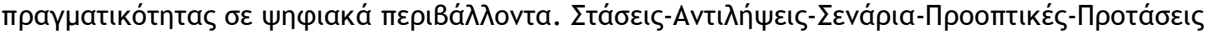




\begin{tabular}{|lc|}
\hline dissatisfied & satisfied \\
\hline Parents & $\mathrm{n}=25.208$ \\
Child 1 & $\mathrm{n}=25.193$ \\
Child 2 & $\mathrm{n}=16.407$ \\
Child 3 & $\mathrm{n}=3.352$ \\
Child 4 & $\mathrm{n}=467$ \\
\hline
\end{tabular}

Figure 5. Mood at home (from dissatisfied $0 \%$ to satisfied $100 \%$ )

The first point of interest is how the general mood at home is perceived. Only a few are 100 percent satisfied; the majority of parents states that their own level of satisfaction is between 5 or 7 (on a scale of $0-10$ ), and the level of their child or children is 8 (Fig. 5) (ibid.). This shows that parents are less satisfied with their own situation at home than the situation of their child or children. (ibid.)

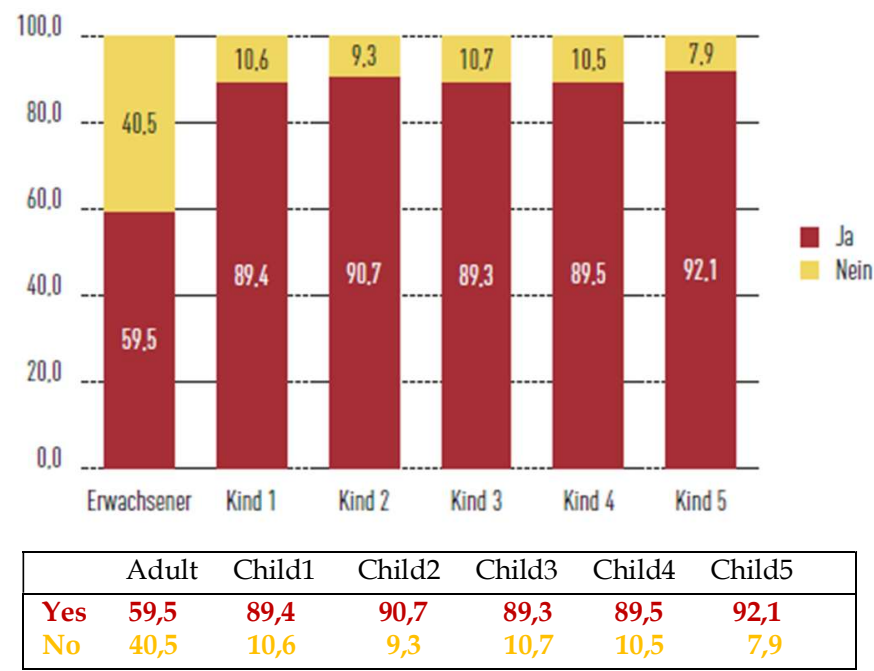

Figure 6. Safe haven at home (in \%)

Figure 6 shows the differences in having a safe haven at home between adults and children in a household. About 90 percent of children have a nearly undisturbed place at home, while more than 40 percent of adults say they have none. Safe havens are an important resource for all family members to get away from daily family life and finally to cope with the multiple stresses. (ibid.)

Summarizing the findings, parents have to react to the new situation and organize everyday life with their children in different living conditions and social security. Adults set their level of satisfaction lower than that of their child or children. Additionally, parents try to allow room for manoeuvre even in the pandemic. The disappearance of the infrastructure for children and young people and the new situation in care, leisure and education services, as well as the reorganization of gainful employment experienced in some cases, affect families differently. For some, everything suddenly takes place at home with the same expectations and challenges. Against what others find new expectations and time. In addition, further challenges of the current developments and the so-called "loosenings" culminate at home.

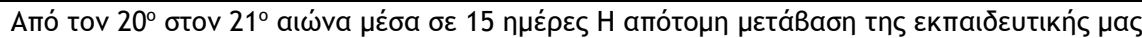

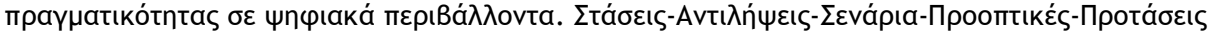




\section{Students and teachers during the school closure}

In the following part, the results of the JIMplus 2020 study are presented. The JIMplus is an additional study to the study series Youth, Information, Media (JIM), which was published in April 2020. For the online survey 1,002 students between the ages of twelve and 19 were asked about how they learn and keep contact during the Corona Lockout in Spring 2020 (mpfs, 2020).

The students said that they coped quite well with the first phase of school closure. Overall, they rated the situation with a grade of 2.5 (rating scale from 1 to 6 ). 16 percent gave a grade of 1 "very well" to the question of how "school at home" worked, with around a third grading "good" (36 percent) or "satisfactory" (32 percent). One in ten tended to have problems and gave a 4 , five percent a grade of 5 and one percent a 6 . The process of home schooling was quite different: 30 percent of the students were given and had assignments when the school closed. Half of the pupils or their parents (56 percent) regularly received tasks by email, and one in ten received work assignments via WhatsApp (mpfs, 2020).

In some classes, teachers worked digitally with their students. One in four (26 percent) used a class chat, around one in five ( 22 percent) was able to access a school cloud, 16 percent met in video conferences. Ten percent used the telephone to get in contact with teachers, and one in four telephoned their classmates on school topics. In the questions about technical devices, the young people answered that they used cell phones (82 percent) and a PC or laptop (80 percent) for school at home. Some of them (26 percent) shared their computer with someone. Most of the students got along well with the software (average grade 1.9). If they had problems, they simply tried it out (63 percent), 35 percent of students received support from their parents and one in five received instructions from the school (21 percent). The technical support provided by friends (14 percent) and siblings (11 percent) was used. Tutorials on the Internet (14percent) were used to (mpfs, 2020).

In the general learning process, the students supported each other via chat (50 percent), 45 percent used tutorials on the Internet, 43 percent received help from their parents, every third person received instructions from the school ( 32 percent), 35 percent simply tried it out. However, the younger students needed more support. 90 percent of 12-to-13-year-old said that their parents helped them with learning. YouTube (83 percent) was predominantly used as a media learning opportunity, followed by Wikipedia (58 percent), documentaries and knowledge programs on television (27 percent) as well as explicit school programs in TV or on the Internet (21 percent). In Germany, only about one fifth of the pupils in secondary schools have a digital learning platform like a school cloud or education applications. The special situation with contact blocking and school closure also had a significant impact on everyday life and media use. The youngsters spent more time than before with YouTube videos (82 percent), listening to music (78 percent), streaming services (71 percent), watching TV (54 percent), going for a walk, and studying (52 percent each).

The usage times were longer in every population group. On average, adolescents spent around two hours per day (121 minutes) with learning and streaming services (114 minutes). Listening to music (100 minutes), YouTube videos (92 minutes) and television (70 minutes) was also used intensively. Boys and girls showed clear differences here, especially when it comes to school effort. Girls spent most of their time for studying (141 minutes), followed by streaming services (128 minutes), and listening to music (106 minutes). Boys on the other hand spent most of the time with YouTube videos (105 minutes), computer games with friends (104 minutes) as well as streaming services, and learning (100 minutes).

Almost all young people contacted friends via messenger, e.g., WhatsApp (90 percent), after all, almost every second person used the phone (48 percent), every third person

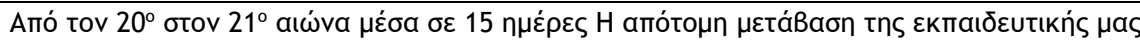

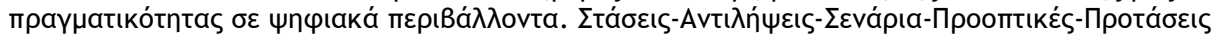


exchanged information via computer games/TeamSpeak (36 percent) or video chats (34 percent), every fourth person used special apps such as house party to stay in touch. In contacting with their grandparents or older relatives, they mainly telephoned (69 percent), almost half used Messengers (46 percent), Video chats were an option for 15 percent and 18 percent made visits. Overall, the survey showed that young people coped well with the corona school situation (mpfs, 2020).

\section{Corona support for Schools}

Since 2019, the Government of Germany supports schools in their process in digitalization. The program is called DigitalPakt, it is financed from the digital infrastructure fund, a so-called special fund that was set up at the end of 2018. Under this program, schools can apply for a digital infrastructure like wireless LAN and for digital devices like notebooks and tablets. The applying system is complicated and not easy to handle for some schools and it take time till they get the decision from the organizing authority. One other critical point of this program is that they do not support teacher trainings (Bundesministerium für Bildung und Forschung, 2020).

\section{How does teachers handle the Corona Crises at schools?}

In a survey from the "Deutsches Schulportal" teachers were asked about how they handle the lockdown at schools and which problems they had. About 30 percent answered that a big problem is the lack of digital equipment of the students. The teachers also pointed out (21 percent) that they have problems to create digital content for their students. The third most mentioned point (16 percent) was problems in the communication with students or parents. The teachers were asked about how they used digital tools and devices before the corona pandemic. 53 percent answered that before the school closure only a quarter or less used digital tools and devices regularly (once a week) in their lessons. All in all, it could be mentioned that Germany has a need to promote digitalization in schools (Das Deutsche Schulbarometer, 2020).

\section{References}

Andresen, S., Lips, A., Möller, R. Rusack, T., Schröer, W., Thomas, S., Wilmes, J. (2020a). Erfahrungen und Perspektiven von jungen Menschen während der Corona-Maßnahmen. Erste Ergebnisse der bundesweiten JuCo. Retrieved 2 July 2020 from https://nbn-resolving.org/urn:nbn:de:gbv:hil2-opus4-10782.

Andresen, S., Lips, A., Möller, R. Rusack, T., Schröer, W., Thomas, S., Wilmes, J. (2020b). Kinder, Eltern und ihre Erfahrungen während der Corona-Pandemie. Erste Ergebnisse der bundesweiter KiCo. Retrieved 2 July 2020 from https://nbn-resolving.org/urn:nbn:de:gbv:hil2-opus4-10817.

Bundesgesetzblatt (2020). Gesetz zum Schutz der Bevölkerung bei einer epidemischen Lage von nationaler Tragweite. Bundesgesetzblatt online 1(14). Retrieved 10 March 2021 from https://www.bgbl.de/xaver/bgbl/start.xav?startbk=Bundesanzeiger_BGBl_bgbl_ $\% 2 \mathrm{~F}_{0} \% 2 \mathrm{~F}^{*} \% 5 \mathrm{~B}$ \%40attr_id=\%27bgbl120s0587.pdf\%27\%5D_1615392389848.

Bundesministerium für Bildung und Forschung (2020). DigitalPakt Schule, (online). Retrieved 20 December 2020 from https:/ / www.bmbf.de/de/wissenswertes-zum-digitalpakt-schule-6496.php.

Das Deutsche Schulbarometer (2020). Spezial Lehrerbefragung zur Corona Krise, (online). Retrieved 20 December 2020 from https:/ / deutsches-schulportal.de/ unterricht/das-deutsche-schulbarometer-spe zial-corona-krise/.

Habermalz, C. (2020). Aufstockung des Digitalpakts Schule. Laptops und Computer für benachteiligte Schüler. Deutschlandfunk. Retrieved 15 May 2020 from https:/ / www.deutschlandfunk.de/aufstockung-desdigitalpakts-schule-laptops-und-computer.680.de.html?dram:article_id=476770.

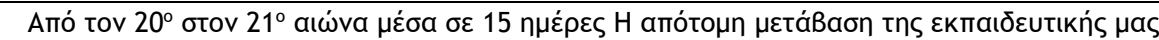

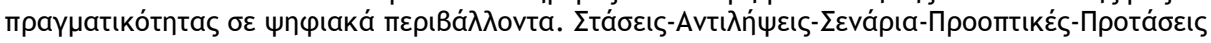


Medienpädagogischer Forschungsverbund Südwest (mpfs) (2020). JimPlus, (online). Retrieved 20 December 2020 from https://www.mpfs.de/studien/jim-studie/jimplus-2020/.

Robert Koch-Institut (RKI) (2017). Nationaler Pandemieplan Teil 1. Strukturen und Maßnahmen. Retrieved 10 March 2021 from https://edoc.rki.de/bitstream/handle/176904/187/28Zz7BQWW2 582iZMQ.pdf? sequence=1\&isAllowed $=\mathrm{y}$.

Verband Deutscher Alten- und Behindertenhilfe (VDAB), 2020. Sonderseite COVID-19 Pandemie. Ereignis-Zeitstrahl. Retrieved 22 December 2020 from https:// www.corona.vdab.de/zeitstrahl/?L=0

Amó tov $20^{\circ}$ бtov $21^{\circ}$ aı

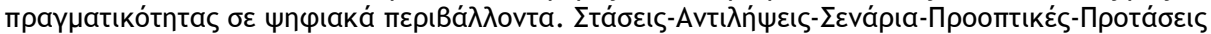

